ISAHP 2005, Honolulu, Hawaii, July 8-10, 2003

\title{
WEB-BASED MULTI-ATTRIBUTES ANALYSIS MODEL FOR MAKE-OR-BUY DECISION
}

\author{
Heung Suk Hwang ${ }^{1}$ \\ Department of Business Administration, Kainan University, Taiwan \\ No. 1 Kainan Rd., Lu-jhu, Taoyuan, 338, Taiwan (R.O.C.) \\ e-mail : hshwang@mail.knu.edu.tw \\ Tel: $+886-3-341-2500$ ext. 6088, Fax : +886-3-341-2176
}

Keywords: AHP, Make-or-buy decision, Fuzzy decision theory

\begin{abstract}
Summary: This paper is concerned with the make-or-buy decision model for manufacturing and procurement problems. We develop a web-based two-step approach such as: 1) the first step, we used the multi-attribute analysis method using AHP(analytic hierarchy process) and 2) second step we used fuzzy set ranking methodologies to integrate the special decision problems that are the problems of multiobjective, multi-criterion, and multi-attributes. We propose a procedure for the comparative judgment and priority for make-or-buy decision and for the optimal resource allocation. First we determine the rank-ordered priority lists of the projects based on the AHP, and then we compute the aggregate fuzzy set rank order. Finally, we develop a systematic and practical program for simple and easy calculation of all the algorithms used in this study. It is found that the proposed model can be validated by comparative computations in various make-or-buy example problems for a cellular manufacturing system.
\end{abstract}

\section{Introduction}

The purpose of this study is to develop an internet/intranet-based solution builder (Solution Builder 2004) for a three-step multi-attribute decision support system to analyze make-or-buy decision problem for manufacturing system. Most of the conventional concepts used in decision support systems do not seem to be appropriate for modeling the manufacturing problems based on the internet/intranet and multiattribute characteristics. In a survey of published decision analysis applications over a 20 -year period, Corner and Corner (1995) concluded that 2/3 of applications used just expected values at the decision criterion and most of applications did not used multi-structured and multi-attributed assessment analysis (Zahedi, 1986). Recently, multi-criteria decision analysis method (Belton and Stewart, 2002) is applied to the scores and weights of multi-level structure of decision system (Saaty, 1981). In this problem, information networks and decision analysis technologies are integrated in one of effective decision support system so as to increase the decision efficiency.

The purpose of this study is to develop an internet/intranet-based solution builder (Solution Builder 2004) for a three-step multi-attribute decision support system using fuzzy-AHP. We used a three-step approach: 1) in step 1, we used brainstorming method for the idea generation, 2) in step 2, we construct decision alternatives and implemented the individual analysis using AHP (analytic hierarchy process) (Barbarosoglu and Yazgas, 1997) and fuzzy set ranking methodology to overcome the special decision problems that are multi-objective, multi-criterion, and multi-attribute problem, and 3) in step 3, we integrated the individual evaluation results of reviewers (Shannon, 1986). We develop web-based computer programs and demonstrate the proposed method for the decision makers to guide an internet/intranet based decision support system. These programs generate the decision alternatives from reviewer's ideas and evaluate each alternative by computing weighted values. Finally, it transforms several individual multi-criteria rank-ordered lists of decision alternatives into one aggregated and

1. Corresponding Author 
prioritized rank-ordered list using the majority-rule method (MRM), a fuzzy set priority method. Considering the results of sample applications of this method, the proposed method can be well fit to the multi-attribute decision problems than the other methods.

In this research, we develop and demonstrate a methodology for the decision makers to guide an internet/intranet based decision support system using proposed method and its computer programs. This method integrates the several individual results of multi-criteria rank-ordered lists of decision alternatives into one aggregated and prioritized rank-ordered list. We performed a literature survey about the majority-rule methods, (a fuzzy set priority method) and these methods were known to be applicable to the aggregation of multiple criteria rank-ordered ordinal priorities. Figure 1 shows this three-step approach of decision support system. We use this decision model in make-or-buy decision problem of manufacturing system and compare the results with that of other methods and show the sample outputs.

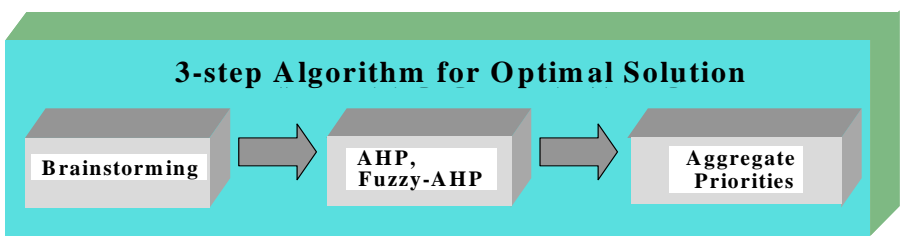

Figure 1. Three-step approach of decision problem

\section{Properties of Make-or-Buy Decision Problem}

The make-or-buy decision problem is known as "sourcing", "outsourcing", or "subcontracting" decision problem (Eilram, 1991) and it will affect all the decision problems in many areas. In any business organization, every time a purchase order is made out something being purchased (Itina, 1994). Behind each purchase order, there is a decision to buy and not to make, and behind each production order is a decision to make and not to buy. It is important to note that the make-or-buy decision problem (Qinn and Mhilmer, 1994) in this study has several properties which are implemented using several analytical tools (Kamarani, 1995). Special attention will be directed towards reviewing those analytical tools and quantitative methods designed to assist practicing managers confronted with a make-or-buy decision problems. Furthermore, a number of questions will be addressed so as to understand some of the properties and issues responsible for differentiating one type of make-or-buy decision problem from the others. These questions may be:

- What backgrounds trigger a make-or-buy decision problem?

- What factors could be considered in make-or-buy decision problem?

- Along which dimensions should make-or-buy decision problem be categorized?

Drtina (1994) has illustrated how the sourcing problem can be extended to the primary activities of the value chain. We believe that Drtina's general approach correctly defines the scope of the problem and represents a useful guide for most sourcing analyses of value chain activities.

The factors that can be influenced any make-or-buy decision problem can be classified into five broad areas as Table 1.

Table 1. Major factors for make-or-buy decision problem (by literatures)

\begin{tabular}{|l|l|}
\hline Performance Measure Criteria & Examples of measurement Parameters \\
\hline$\cdot$ Cost & - Total unit cost \\
- Quality & - Internal failure cost-scrap, rework, rejected \\
- Delivery speed & - delivery lead time \\
- Delivery reliability & - Percentage of on-time delivery \\
-Volume flexibility & - Average volume fluctuation \\
- Product flexibility & - Number of component substitutions made \\
& over a given time period. \\
\hline
\end{tabular}


The range of sourcing structure found in the industry can be considered by the methodology as shown in Figure 2 (Ellrang, 1991, Quinn, 1994). For the performance assessment of make-or-buy decision problem, we recommended the use of the parameters by Leong, Snyder, and Ward (1990) as shown in Table 2.
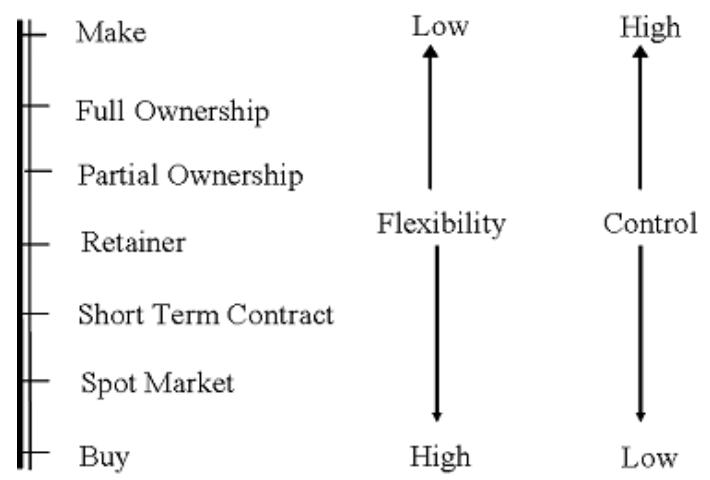

Figure 2. Range of source structure of make-or-buy decision problem

Table 2. Example of performance evaluation of make-or-buy decision problem

\begin{tabular}{|l|l|}
\hline \multicolumn{1}{|c|}{ Item } & \multicolumn{1}{c|}{ Major Factors } \\
\hline \multirow{3}{*}{ Manufacturing } & - Importance of technology for competitive advantage \\
Technology & - Maturity of technology \\
& - Technology uncertainty \\
& - Probability of future improvements \\
\hline \multirow{3}{*}{ Out Source Risk } & - Appropriation risk \\
& - Technology diffusion \\
& - End-product degradation \\
& - Benchmarking \\
\hline \multirow{3}{*}{ Managerial Issues } & - Workforce stability \\
& - Complexity level in planning, control, or supervision \\
& - Assurance and reliability of supply \\
& - Benchmarking \\
\hline \multirow{3}{*}{ Financial Issues } & - Cost \\
& - Investment \\
& - Return on investment \\
\hline \multirow{3}{*}{ Operational Issues } & - Manufacturing capability \\
& - Quality \\
& - lead time \\
& - Volume uncertainty \\
\hline
\end{tabular}

There are many methods available to decide the weighted value and analyzing the hierarchical structured and multi attribute problems, however in this study we develop and use the web-based three step decision analysis model to analyze the make-or-buy decision problem.

\section{Three-step Approach of Decision Analysis}

In this study, we develop a solution builder using GUI-type simulation software as shown in Figure 4. In the first step, to create the ideas to drive out alternatives from a group reviewer, we use brainstorming method based on internet/intranet, and in the second step, we use Fuzzy-AHP method to evaluate the decision alternatives and determine the preferred alternatives. In the last step, we integrate the results of individual evaluations into one ranked order. We develop two heuristic methods based on majority rule methods. Figure 3 shows a schematic structure of three-step approach of decision support system. It is known that the proposed solution builder can be used as a decision support tool for project evaluation, personal or public project evaluation based on internet/intranet network. 


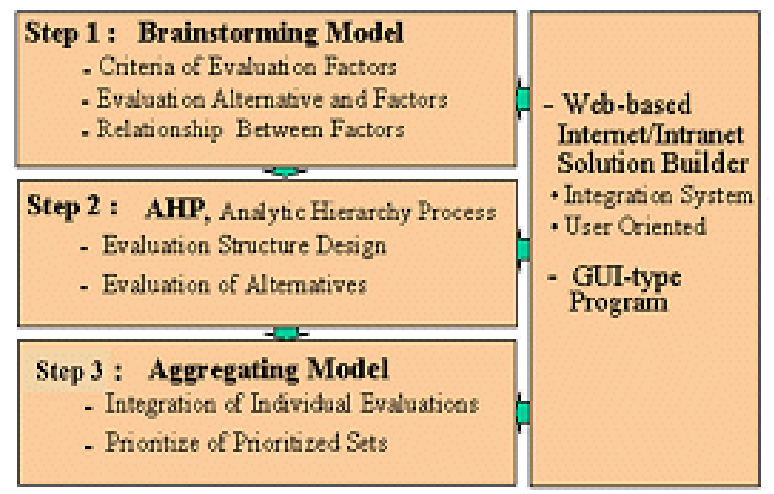

Figure 3. 3-step approach of decision support system of solution builder (Hwang, 2004, 2002)

\subsection{Brainstorming}

The alternative evaluation and its method can be determined based on the system attributes and experiences of evaluators. For the model structure and alternatives include the group decision ideas, and to create the ideas of alternatives for decision support system analysis of various groups, we used a brainstorming method. We developed a GUI-type program for users to use this method in network-based environment without any problems. Example problems of make-or-buy decision problems of manufacturing system are tested. The decision structure and its method can be determined based on the system attributes and experiences of evaluators. To construct the decision structure and alternatives and to include all the group decision ideas, we used a brainstorming process.

\subsection{Fuzzy-AHP Method}

The theory of fuzzy sets has extended traditional mathematical decision theories so that they can cope well with any vagueness problem which cannot adequately be treated by probability distributions. The concepts and rules of fuzzy decision making provide us with the necessary tools for structuring a decision from a kind of information. The model used in this study had a limited capability in studying the fuzzy set priority that could be obtained from the summed frequency matrix of Shannon (1986) method. From the Shannon's summed frequency matrix for complementary cells, $A_{i j}$ and $A_{j i}$, an additional fuzzy set matrix was made by considering $A_{i j}=1-A_{j i}$ for all cells. The fuzzy matrix complement cell values sum to 1 and fuzzy set difference matrix is defined as follows:

$$
\begin{aligned}
R-R^{T} & =\mathrm{U}(\mathrm{A}, \mathrm{B})-\mathrm{U}(\mathrm{B}, \mathrm{A}), & \text { if } \mathrm{U}(\mathrm{A}, \mathrm{B})>\mathrm{U}(\mathrm{B}, \mathrm{A}), \\
& =0, & \text { otherwise }
\end{aligned}
$$

where, for $U(A, B)$ quantifies, $A$ is preferable to $B$.

To obtain fuzzy preferences, the following five steps were considered:

Step 1 : Find the summed frequency matrix (using Shannon method)

Step 2 : Find the fuzzy set matrix $\mathrm{R}$ which is the summed frequency matrix divided by the total number of evaluators

Step 3: Find the difference matrix

$$
\begin{aligned}
R-R^{T} & =\mathrm{U}(\mathrm{A}, \mathrm{B})-\mathrm{U}(\mathrm{B}, \mathrm{A}), \text { if } \mathrm{U}(\mathrm{A}, \mathrm{B})>\mathrm{U}(\mathrm{B}, \mathrm{A}), \\
& =0 \quad \text { otherwise }
\end{aligned}
$$

where, for $\mathrm{U}(\mathrm{A}, \mathrm{B})$ quantifies, $\mathrm{A}$ is preferable to $\mathrm{B}$.

Step 4 : Determine the portion of each project that is not dominated as follows :

$$
A_{\text {ColA }}^{N D}=1-\max \left(X_{1 . \text { ColA }}, X_{2 . \text { ColA }}, \ldots, X_{n . \text { ColA }}\right)
$$

Step 5: The priority of the fuzzy set is then the rank order of XND values with a decreasing order. An example is shown as follows: 


$$
\begin{aligned}
R & =\left[\begin{array}{llll}
0.0 & 0.8 & 0.6 & 0.6 \\
0.2 & 0.0 & 0.0 & 0.4 \\
0.4 & 0.1 & 0.0 & 0.4 \\
0.4 & 0.6 & 0.6 & 0.0
\end{array}\right] \quad R^{T}=\left[\begin{array}{llll}
0.0 & 0.2 & 0.4 & 0.4 \\
0.8 & 0.0 & 0.1 & 0.6 \\
0.6 & 0.0 & 0.0 & 0.6 \\
0.6 & 0.4 & 0.4 & 0.0
\end{array}\right] \\
R-R^{T}= & {\left[\begin{array}{llll}
0.0 & 0.6 & 0.2 & 0.2 \\
0.0 & 0.0 & 0.0 & 0.0 \\
0.0 & 0.1 & 0.0 & 0.0 \\
0.0 & 0.2 & 0.2 & 0.0
\end{array}\right] } \\
X_{A}^{N D}=1 & -\operatorname{Max}(0.0)=1-0.0=1.0, \quad X_{B}^{N D}=1-\operatorname{Max}(1.0)=1-0.6=0.4 \\
X_{C}^{N D}=1 & -\operatorname{Max}(0.2)=1-0.2=0.8, \quad X_{D}^{N D}=1-\operatorname{Max}(0.2)=1-0.2=0.8
\end{aligned}
$$

Thus, the fuzzy set priority score is given by $1.0>0.8>0.8>0.4$ and the alternative priority is given by $\mathrm{A}>\mathrm{C}>\mathrm{D}>\mathrm{B}$.

\subsection{Integration of Individual Evaluations}

For the integration of the results of individual evaluations and prioritized sets, we use two heuristic models which are a kind of majority-rule methods. These methods are compared to determine the most preferred model for the make-or-buy decision support system.

\section{1) Heuristic 1}

In this method the preference score is given by the sum of the marks received from the evaluators, where for $m$ alternatives, the marks are given, in decreasing order preference, $(\mathrm{m}-1),(\mathrm{m}-2), \ldots ., 0$. The ranking was based on the scores of each alternatives. In this case, the highest score is determined to be the first

\begin{tabular}{|c|c|c|c|}
\hline Alt. & $\begin{array}{l}\text { Preference } \\
\text { Matrix }\end{array}$ & Raw Sum & Weighed Value \\
\hline $\begin{array}{l}\text { Alt. A } \\
\text { Alt. } \\
\text { Alt. } \\
\text { C }\end{array}$ & $\begin{array}{lll}0.0 & 1.0 & 1.0 \\
4.0 & 0.0 & 2.0 \\
4.0 & 3.0 & 0.0\end{array}$ & $\begin{array}{l}2.0 \\
6.0 \\
7.0\end{array}$ & $\begin{array}{l}0.133 \\
0.400 \\
0.467\end{array}$ \\
\hline $\begin{array}{l}\text { Heuristic method } 1 \\
\text { Rank order }\end{array}$ & \multicolumn{3}{|c|}{$\mathrm{C}>\mathrm{B}>\mathrm{A}$} \\
\hline
\end{tabular}
priority. A sample result of the heuristic method 1 that applied in an example problem with $\mathrm{N}=5$ evaluators and $\mathrm{M}=3$ alternatives is given as following:

Table 3. Example result of heuristic method 1

Evaluator $1: \mathrm{B}>\mathrm{A}>\mathrm{C}$, Evaluator $2: \mathrm{B}>\mathrm{C}>\mathrm{A}$, Evaluator $3: \mathrm{C}>\mathrm{A}>\mathrm{B}$,

Evaluator 4: $\mathrm{C}>\mathrm{B}>\mathrm{A}$, Evaluator 5: $\mathrm{C}>\mathrm{B}>\mathrm{A}$.

The value of each cell of basic evaluation score matrix is given by one if the raw alternative wins against the column alternative, otherwise given by 0 . In the summed frequency matrix, the weighted value of the raw sum is the basis of rank order, thus the Heuristic Method 1 rank order is given by,

$\mathrm{C}(0.467)>\mathrm{B}(0.400)>\mathrm{A}(0.133)$

2) Heuristic 2

In this heuristic method, first the preference matrix is developed by a comparison of the scores in the component cells $(\mathrm{A}, \mathrm{B}$ versus $\mathrm{B}, \mathrm{A})$. If the cell $(\mathrm{A}, \mathrm{B})$ value equals to $(\mathrm{B}, \mathrm{A})$, then each component cell in the matrix is given by " $1 / 2$ ". On the other hand if the $(A, B)$ value is greater than the $(B, A)$, then $(A, B)$ is given by " 1 " and $(\mathrm{B}, \mathrm{A})$ cell of the preference matrix is given by 0 . The alternatives are ranked by the order of their preference matrix row sums. The result of the same sample problem of Heuristic Method 1 by applying the Heuristic Model 2 is given by

$$
\mathrm{C}(0.450)>\mathrm{A}(0.392)>\mathrm{B}(0.158) \text {. }
$$




\section{3) Fuzzy Set Priority Method}

The theory of fuzzy sets has extended traditional mathematical decision theories so that they can cope with the kind of vagueness which cannot adequately be represented by probability distributions. The fundamental concept of fuzzy set priority relation $\mathrm{R}$ is derived from the result of heuristic model 2 . From the summed frequency matrix for complementary cells, $A_{i j}$ and $A_{i j}$ an additional fuzzy set matrix is made by considering Aij $=1-A_{j i}$ for all cells. The fuzzy matrix complement cell values sum to be 1 .

By applying the fuzzy set priority model to the same example of Heuristic Method, the result is given by $\mathrm{A}(0.38)>\mathrm{C}(0.31)>\mathrm{B}(0.01)$.

\section{4) Computer Program Development}

We developed the computer program using C-language through the use of the module based tool and applied to a set of example problems of multi-structured decision support system. The schematic flow diagram of the model is shown in Figure 4. Table 3 presents the comparison of sample runs between two heuristic and fuzzy set priority methods. We applied this model to a set of examples of multi-structured decision support system as shown in Figure 4.

First, we determined the weighted values by heuristic method and also by fuzzy -AHP method.

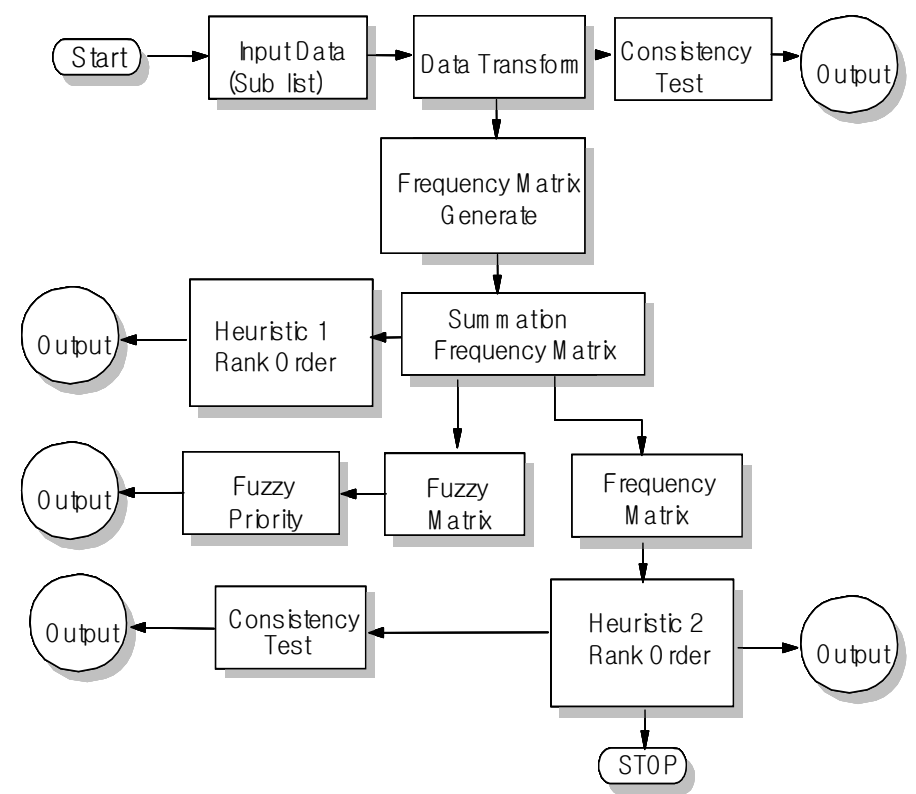

Figure 4. Schematic Flow Diagram of the Proposed Model

\section{Make-or Buy Decision Analysis in Cellular Manufacturing System}

We used the AHP and fuzzy set ranking methodologies in make-or-buy decision making for both multi objective programming and fuzzy-AHP method to overcome the difficulties of special decision problems; those of multi-objective, multi-criterion, and multi-attributes structures of manufacturing system. We used the 3-step decision approaches and we developed a systemic and practical computer program to solve the problems in the proposed methods. For the computational experiments we applied in cellular manufacturing system. Thus, fuzzy-AHP is used for make-or-buy decision making in manufacturing systems as following:

1) Make-or-buy decision making,

2) Determine the weighted value of each decision factors,

3) Resource allocation in manufacturing process.

\subsection{Cellular Manufacturing System}

Generally, the cellular manufacturing system uses many kinds of machines and tools and its manufacturing process is a little bit complicated than the conventional production systems. 


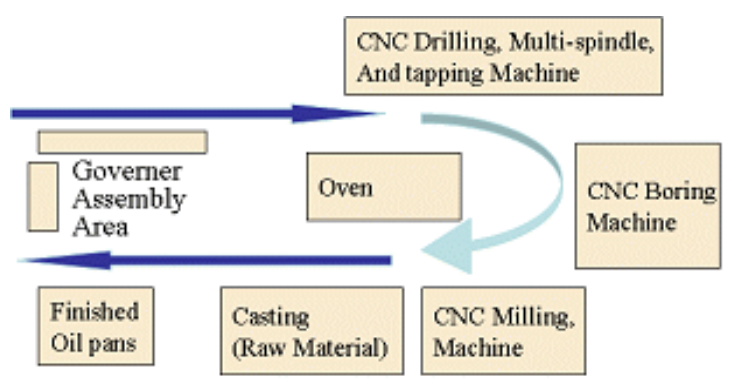

Figure 5. Oil pan manufacturing cell layout (ex:)

In this study we used an oil pan manufacturing cell layout as an example problem as shown in Figure 5. This system produces oil pan by 120 lot size, and uses two workers. The machines consisted of CNC machines (milling machine, boring machine, multi-spindle and drilling) this CNC cell produces oil pan by given lot sizes.

\subsection{Make-or-buy Decision of Cellular Manufacturing System Using AHP and fuzzy-AHP}

For this problem we used three-step method using fuzzy-AHP method. To decide the decision structure and alternatives we used the group decision ideas, and to create the ideas of alternatives for decision support system analysis of various groups, we used a brainstorming method. Figure 5 and 6 show the sample outputs of alternative generation and construct the decision structure of the example of cellular manufacturing problem.

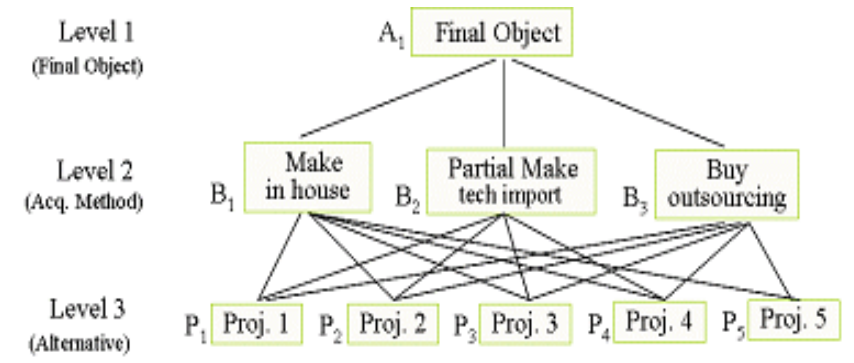

Figure 5. Sample output of AHP structure (Oil pan manufacturing cell)

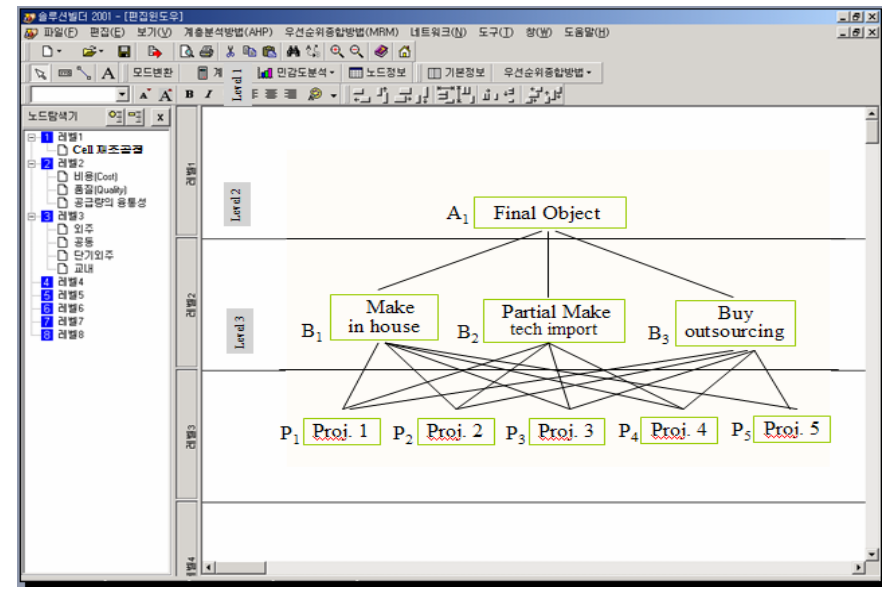

Figure 6. Sample Output of AHP structure of cellular manufacturing system

In each decision level, we computed the weighted values as in Figure 7. Table 4 summarized the integrated preference priority of this problem using heuristic and fuzzy reasoning method. 


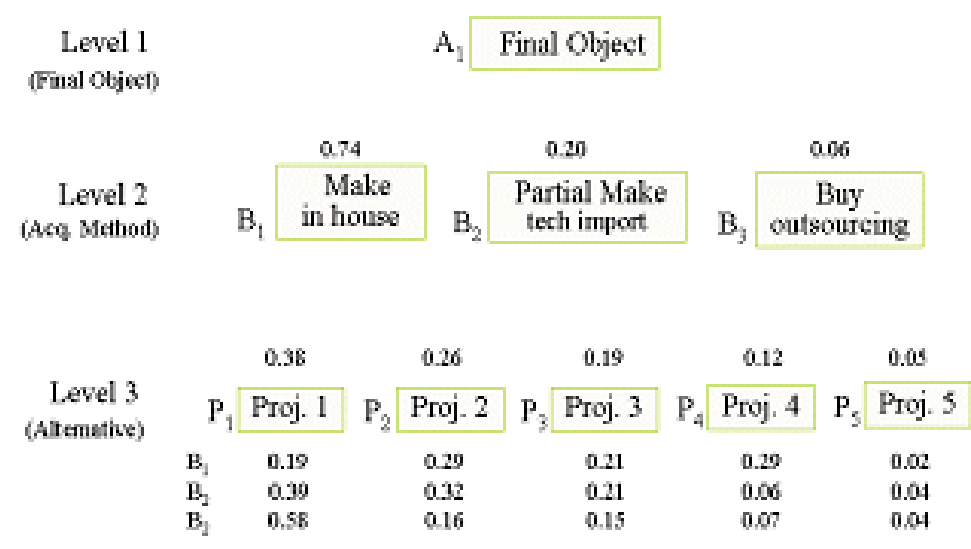

Figure 7. Weighted value of evaluation factors

Using the Heuristic 1, Heuristic 2, AHP, and fuzzy set ranking methods, we integrated the results of the individual reviewers analysis as following,

where, $\mathrm{B}_{1}$ : make in house not outsourcing,

$\mathrm{B}_{2}$ : partial make in house and partial out sourcing for technology,

$\mathrm{B}_{3}$ : all outsourcing,

$\mathrm{P}_{1}, \cdots, \mathrm{P}_{5}$ : cellular manufacturing alternatives

Table 4. Results of Integrated Priority

\begin{tabular}{|l|l|}
\hline Majority Rule used & Priority by Alternative \\
\hline 1. Heuristic model 1 & $\mathrm{~B}_{1}(0.70), \mathrm{B}_{2}(0.18), \mathrm{B}_{3}(0.12)$ \\
& $\mathrm{P}_{1}(0.29), \mathrm{P}_{2}(0.30), \mathrm{P}_{3}(0.18), \mathrm{P}_{4}(0.15), \mathrm{P}_{5}(0.08)$ \\
\hline 2. Heuristic model 2 & $\mathrm{~B}_{1}(0.73), \mathrm{B}_{2}(0.23), \mathrm{B}_{3}(0.05)$ \\
& $\mathrm{P}_{1}(0.36), \mathrm{P}_{2}(0.27), \mathrm{P}_{3}(0.13), \mathrm{P}_{4}(0.15), \mathrm{P}_{5}(0.09)$ \\
\hline $\begin{array}{l}\text { 3. Fuzzy Set Ranking } \\
\text { Method }\end{array}$ & $\mathrm{B}_{1}(0.74), \mathrm{B}_{2}(0.20), \mathrm{B}_{3}(0.06)$ \\
& $\mathrm{P}_{1}(0.38), \mathrm{P}_{2}(0.26), \mathrm{P}_{3}(0.19), \mathrm{P}_{4}(0.12), \mathrm{P}_{5}(0.05)$ \\
\hline
\end{tabular}

For this example, we could conclude the best cellular manufacturing system method is the alternative $\mathrm{B}_{1}$ (make in house not outsourcing) and the best alternative of this cellular manufacturing system is $\mathrm{P}_{1}$. To overcome the uncertainty and the discrete points of data (in pair wise matrix), the fuzzy-AHP method and Fuzzy set ranking method is one of good method.

\section{Resource Allocation in Cellular Manufacturing System}

We can use the AHP weighted values in resource allocation of manufacturing works so as to be allocated first for the high priority alternative work. We can formulate this problem by linear programming problem using AHP weighted values. For the budget allocation problem for this cellular manufacturing works (alternatives) using the weighted values of level 2, we formulated as following optimization problem.

$$
\begin{array}{ll}
\operatorname{Max} & \sum_{i=1}^{n} \sum_{j=1}^{m} W_{i j} X_{i j} \\
\text { s.t. } & \sum_{i=1}^{m} C_{i j} X_{i j} \leq B_{i} \quad i=1,2, \ldots, \mathrm{m}, \\
& 0 \leq X_{i j} \leq 1 \text { or } X_{i j}=0,1 \quad \forall i, j
\end{array}
$$

$W_{i j}$ : ith area jth alternative priority, $C_{i j}$ : the required cost of ith area jth alternative, $X_{i j}$ : variable of $i$ th area $j$ th alternative working 
This problem can be solved by linear programming and 0-1 programming method. Table 5 and 6 show a sample solution of these methods.

Table 5. Example data of resource allocation of cellular product alternatives

\begin{tabular}{|c|l|c|c|c|}
\hline $\begin{array}{c}\text { Make-or-buy } \\
\text { alternative }\end{array}$ & $\begin{array}{l}\text { Available } \\
\text { Budget } \\
\text { unit :\$100,000 }\end{array}$ & Alternative & $\begin{array}{l}\text { Priority } \\
\text { Vector }\end{array}$ & $\begin{array}{l}\text { Required Cost } \\
\text { Unit: million\$ }\end{array}$ \\
\hline & & P1 & 0.19 & 11000 \\
B1 & & P2 & 0.29 & 9000 \\
(Make in House) & 25000 & P3 & 0.21 & 12000 \\
& & P4 & 0.29 & 8000 \\
& & P5 & 0.02 & 7000 \\
B2 & & P1 & 0.39 & 4000 \\
(partly make with & \multirow{2}{*}{18000} & P2 & 0.32 & 5000 \\
tech. outsource) & & P3 & 0.21 & 6000 \\
& & P4 & 0.06 & 5000 \\
& & P5 & 0.04 & 3000 \\
\hline B3 & & P1 & 0.58 & 4000 \\
(Outsource) & 11000 & P3 & 0.16 & 3000 \\
& & P4 & 0.15 & 5000 \\
& & P5 & 0.04 & 2000 \\
\hline Total & 54000 & \multicolumn{3}{|l}{} \\
\hline
\end{tabular}

$$
\begin{array}{ll}
\text { Max } Z=0.19 X_{11}+0.29 X_{12}+0.21 X_{13}+0.29 X_{14}+0.02 X_{15}+0.39 X_{21}+0.32 X_{22}+0.21 X_{23} \\
& +0.06 X_{24}+0.04 X_{25}+0.58 X_{31}+0.16 X_{32}+0.15 X_{33}+0.07 X_{34}+0.04 X_{35} \\
\text { s.t. } \quad & 11000 X_{11}+9000 X_{12}+12000 X_{13}+8000 X_{14}+7000 X_{15} \leq 25000 \\
& 4000 X_{21}+5000 X_{22}+6000 X_{23}+5000 X_{24}+3000 X_{25} \leq 18000 \\
& 4000 X_{31}+3000 X_{32}+5000 X_{33}+2000 X_{34}+1000 X_{35} \leq 11000 \\
& \text { where, } X_{i j}=0,1 \quad \forall i, j
\end{array}
$$

Table 6. Sample output of resource allocation of cellular product alternatives

\begin{tabular}{|c|c|c|c|c|c|}
\hline Make-or-buy method & \multicolumn{2}{|c|}{ Opt. Sol } & $\begin{array}{c}\text { Required Cost } \\
\text { Unit: } 100,000 \$\end{array}$ & $\begin{array}{c}\text { Budget Allocation } \\
\text { Unit: 00,000 \$ }\end{array}$ & All. Result \\
\hline & $\mathrm{P}_{1}$ & $\mathrm{X}_{11}=0.0$ & 11000 & 0.000 & Delete \\
B1 & $\mathrm{P}_{2}$ & $\mathrm{X}_{12}=1.0$ & 9000 & 9000 & Accept \\
(Make in House) & $\mathrm{P}_{3}$ & $\mathrm{X}_{13}=1.0$ & 12000 & 12000 & Accept \\
& $\mathrm{P}_{4}$ & $\mathrm{X}_{14}=0.0$ & 8000 & 0.000 & Delete \\
& $\mathrm{P}_{5}$ & $\mathrm{X}_{15}=0.0$ & 7000 & 0.000 & Delete \\
\hline & $\mathrm{P}_{1}$ & $\mathrm{X}_{21}=1.0$ & 4000 & 4000 & Accept \\
B2 & $\mathrm{P}_{2}$ & $\mathrm{X}_{22}=1.0$ & 5000 & 5000 & Accept \\
(partly make & $\mathrm{P}_{3}$ & $\mathrm{X}_{23}=1.0$ & 6000 & 6.000 & Accept \\
with tech. outsource) & $\mathrm{P}_{4}$ & $\mathrm{X}_{24}=0.0$ & 5000 & 5000 & Accept \\
& $\mathrm{P}_{5}$ & $\mathrm{X}_{25}=1.0$ & 3000 & 3000 & Accept \\
\hline \multirow{5}{*}{ B3 } & $\mathrm{P}_{1}$ & $\mathrm{X}_{31}=1.0$ & 4000 & 4000 & Accept \\
& $\mathrm{P}_{2}$ & $\mathrm{X}_{32}=1.0$ & 3000 & 3000 & Accept \\
(Outsource) & $\mathrm{P}_{3}$ & $\mathrm{X}_{33}=0.0$ & 5000 & 0.000 & Delete \\
& $\mathrm{P}_{4}$ & $\mathrm{X}_{34}=1.0$ & 2000 & 2000 & Accept \\
& $\mathrm{P}_{5}$ & $\mathrm{X}_{35}=1.0$ & 1000 & 1000 & Accept \\
\hline Total & $\mathrm{Z}=1.013$ & 69000 & 44000 & \\
\hline \multicolumn{5}{|c|}{} \\
\hline
\end{tabular}




\section{Summary and Conclusions}

We developed a three-step approach of web-based make-or-buy decision model for multi-structured decision support systems in the view point of multi-attribute evaluation. Those steps are: 1) brainstorming to define the alternatives and performance evaluation factors, 2) individual evaluation of the alternatives using fuzzy-AHP, heuristic and fuzzy set reasoning methods, and 3) integration of the individual evaluations using majority rule method. Finally, for a simple and efficient computation purpose, we developed a systematic and practical program to calculate all the algorithms. The model was applied to a cellular manufacturing system problem for the purpose of comparative validation. The results of various multi-structured decision support examples for make-or-buy decision analysis and also resource allocation problems are shown by Tables and by Figures. By the sample results of both AHP and fuzzy set reasoning methods, it is known that the proposed model is a good method for the performance evaluation of multi-attribute and multiple goals for make-or-buy decision problems.

\section{References}

Blin, J. M. (1974), Fuzzy Relations in Group Decision Theory, International Journal of Cybernetics, Vol.4, No.2, pp.17-22.

Barbarosoglu, G. \& Yazgas, T. (1997), Application of the analytic hierarchy process to the supplier selection problem, Production and Inventory Management Journal, Vol.38, No.1, pp.14-21.

Ching-Hsue Cheng (1996), Evaluating Naval Tactical Missile Systems by Fuzzy AHP Based on the Grade Value of Membership Function, European Journal of Operation Research, Vol. 96, pp.343-350.

Dritina, R.E. (1994), The Outsourcing Decision, Management Accounting, March, pp 56-62.

Eilram, L. M. (1991), Supply Chain Management: The Industrial organization Perceptive, International Journal of Physical Distribution \& Logistics Management, Vol.21, No 1, pp.13-22.

Fishburn, P. C.(1970), Utility Theory for Decision Making, New York, John Wiley and Sons, pp. 227 ,

Itina, R.E. (1994), The Outsourcing Decision, Management Accounting, pp.56-62.

Kamarani, A.K. (1995), Planning, Design, and Analysis of Cellular Manufacturing Systems, Elsevier.

Heung-Suk Hwang (2002), "Web-based Decision Support System-Multi-attribute and Fuzzy Reasoning Approach", Journal of Dongeui University, Vol. 36, pp.377-388.

Heung-Suk Hwang (2004), "Web-based Multi-Attribute Analysis Model for Engineering Project Evaluation”, International Journal of Computers \& Industrial Engineering, Vo. 46. 1, pp. 669-678,

Leung Y.T. and R. Sure,(1990), Performance Evaluation of Discrete Manufacturing Systems, IEEE Control Systems Magazine, Vol. 10, No.4, pp.77-86.

Leong, G.K. Snyder, D.L., \& Ward, P.T. (1990). Research in the Process and Content of Manufacturing Strategy, OMEGA International Journal of Management Science, 18(2), 109-122.

Murphy C. K. (1995) Limits on the Analytic Hierarchy Process from Its Consistency Index, European Journal of Operation Research, 65, pp. 138-139.

Qinn, J.B., \& MHilmer, F.G. (1994), Strategic Outsourcing, Sloan Management Review, Summer, 43-55.

Shannon, R.E, (1986), The Amalgamation of Group Opinions or Evaluations, Journal of Industrial Engineering, Vol. 19, No.6.

Saaty, T. L. (1981), The Analytic Hierarchy Process, McGraw-Hill, New York.

Zahedi, F.(1986), The analytic Hierarchy Process - A Survey of the Method and it's Applications, Interfaces, Vol. 16, No. 4, pp.96-104. 